\title{
PENGELOLAAN DANA DESA DI KECAMATAN BALONG KABUPATEN PONOROGO
}

\author{
Maretha Berlianantiya \\ Universitas PGRI Madiun \\ maretha@unipma.ac.id ${ }^{1)}$, ridwanekawardani03@.gmail.com ${ }^{2)}$
}

\begin{abstract}
Poverty often occurs in rural areas rather than urban areas, low education which results in low quality of human resources and lack of access is often the cause of rural poverty. In addition, most of the economies of rural communities rely solely on the traditional agricultural sector. Various poverty reduction policies have been implemented, including village fund policies. This study aims to examine the management of village funds in the Balong sub-district of Madiun Regency with a case study in the villages of Tatung and Karangmojo villages covering the management of village funds in Tatung village and Karangmojo village. Balong Subdistrict and the impact of empowerment in the villages of Tatung and Karangmojo, Balong District. This research was conducted in Balong Subdistrict, Ponorogo Regency with a Case study in Tatung Village and Karangmojo Village with qualitative methods. In the village of Tatung village funds are managed as tourist villages with a focus on Paragliding tourist rides. Whereas in Karangmojo village it is used for Bumdes in the form of Lovebird birds, providing Gapoktan assistance, and infrastructure development.
\end{abstract}

Keywords: Poverty, Village Funds

\begin{abstract}
Abstrak
Kemiskinan sering terjadi di pedesaan dari pada perkotaan, rendahnya pendidikan yang mengakibatkan rendahnya kualitas sumber daya manusia dan kurangnya akses seringkali menjadi penyebab kemiskinan di pedesaan. Selain itu kebanyakan perekonomian masyarakat desa hanya mengandalkan sector pertanian secara tradisional. Berbagai kebijakan penanggulangan kemiskinan sudah banyak dilaksanakan, termasuk kebijakan dana desa. Penelitian ini bertujuan untuk mengkaji pengelolaan dana desa di kecamatan Balong Kabupaten Madiun dengan studi kasus di desa Tatung dan desa Karangmojo meliputi pengelolaan dana desa di desa Tatung dan desa Karangmojo Kecamatan Balong serta dampak dari pemberdayaan di desa Tatung dan Karangmojo Kecamatan Balong. Penelitian ini dilakukan di Kecamatan Balong Kabupaten Ponorogo dengan studi Kasus di Desa Tatung dan Desa Karangmojo dengan metode kualitatif. Di Desa Tatung dana desa dikelola sebagai desa wisata dengan fokus ke wahana wisata Paralayang. Sedangkan di desa Karangmojo digunakan untuk Bumdes berupa ternak burung Lovebird, memberi bantuan Gapoktan, dan pembangunan infrastruktur.
\end{abstract}

Kata Kunci: Kemiskinan, Dana Desa 


\section{PENDAHULUAN}

Kemiskinan merupakan salah satu masalah besar di setiap Negara. Menurut worldbank kemiskinan adalah sedangkan hidup dengan pendapatan di bawah 2 dollar per hari. Kemiskinan sering terjadi di pedesaan dari pada perkotaan, rendahnya pendidikan yang mengakibatkan rendahnya kualitas sumber daya manusia dan kurangnya akses seringkali menjadi penyebab kemiskinan di pedesaan. Selain itu kebanyakan perekonomian masyarakat desa hanya mengandalkan sector pertanian secara tradisional. Hal ini tidak bisa dibiarkan terus menerus karena bisa menghambat salah satu tujuan dari pembangunan ekonomi Indonesia tentang mengurangi angka kemiskinan. Sehingga diperlukan solusi penyelesaian permasalahan kemiskinan. Sebenarnya Pemerintah Indonesia selama ini telah banyak mengeluarkan kebijakan - kebijakan untuk mengatasi masalah kemiskinan antara lain pemberian bantuan Raskin (beras Miskin), PNPM, BLSM namun kebanyakan berbagai program pengentasan kemiskinanan cenderung belum efektif karena kurang menjamin kearah usaha produktif yang berkelanjutan secara mandiri. Masih adanya ego sektoral masih cukup dominan dalam program pengentasan kemiskinan, sehingga anggaran tidak mengarah pada investasi jangka panjang, melainkan pada penerapan program yang masih berorientasi proyek dan bukan output program.

Pada masa pemerintahan Joko widodo sekarang ini melalui salah satu program Nawacita yaitu tentang membangun desa dari pinggiran dengan memperkuat daerah daerah dan desa dalam kerangka Negara kesatuan. Menurut Undang-Undang Nomor 6 Tahun 2014 mengamanatkan tentang pemberian Dana Desa. Dana desa dianggarkan setiap tahun dari APBN (Anggaran Pendapatan dan Belanja Negara) yang diberikan kepada setiap desa sebagai salah satu sumber pendapatan desa dan diprioritaskan untuk pelaksanaan pembangunan dan pemberdayaan masyarakat desa. Pada 2018 anggaran Dana Desa mencapai Rp 60 triliun untuk 74.958 desa di seluruh Indonesia. (www. Kemenkeu. go.id) . Tujuan dari dana desa antara lain 1, meningkatkan pelayanan publik di desa, mengentaskan kemiskinan, memajukan perekonomian desa, mengatasi kesenjangan pembangunan antar desa, memperkuat masyarakat desa sebagai subyek dari pembangunan.

Dana Desa Tahun Anggaran 2018 telah dialokasikan sebesar Rp. 60 triliun kepada 74.958 desa, dengan ketentuan sebagai berikut: Alokasi Dasar (AD), sebesar $77 \%$ dari pagu atau sebesar Rp. 46.200,00 miliar, dibagi secara merata kepada setiap desa b. Alokasi Afirmasi (AA), sebesar $3 \%$ dari pagu atau Rp. $1.800,00$ dibagi secara proporsional kepada desa tertinggal dan desa sangat tertinggal yang mempunyai jumlah penduduk miskin (JIPM) tinggi, c. Alokasi Formula (AF) sebesar $20 \%$ dari pagu atau Rp. 12.000,00 miliar yang dibagi berdasarkan : 1) Jumlah penduduk desa dengan bobot $10 \%$, 2) Jumlah penduduk miskin desa dengan bobot $50 \%, 3$ ) luas wilayah desa dengan bobot $15 \%$, dan indeks kemahalan konstruksi atau Indeks kesulitan geografis desa dengan bobot $25 \%$.

Kecamatan Balong Kabupaten Ponorogo Jawa Timur merupakan salah satu kecamatan di Indonesia yang mendapatkan alokasi dana desa. Terdapat 20 desa di kecamatan Balong yang semuanya mendapatkan alokasi dana desa. Kecamatan Balong mendapat alokasi dana sebesar Rp. 7.731.310.000 dibagi 20 desa dengan rata - rata setiap desa mendapatkan Rp. 386.565.500. untuk mengelola dana desa agar dapat dipergunakan sesuai prioritas yang ditetapkan dan tidak terjadi penyimpangan sehingga tujuan dari dana desa dapat tercapai maka juga diperlukan evaluasi. 
Desa Tatung dan Desa Karangmojo adalah dua desa yang menggunakan dana desa sebagai desa wisata dan perbaikan infrastruktur. Ke dua desa ini sama - sama memperdayakan masyarakat. Selama ini masyarakat desa Tatung dan Desa Karangmojo memiliki pendidikan yang rendah dan $70 \%$ bekerja di sektor pertanian. Pemuda desa ini kebanyaakan setelah lulus sekolah jarang melanjutkan ke perguruan tinggi dikarenakan faktor ketidakmampuan pendapatan keluargannya sehingga mereka kebanyakan melakukan urbanisasi ke kota bahkan lebih memilih bekerja sebagai tenaga kerja ke luar negeri atau buruh migran. Disamping itu menurut mereka jika pemuda desa masih menetap di desa maka tidak akan ada perbaikan kehidupan secara ekonomi bagi mereka.

Penelitian ini bertujuan untuk mengkaji pengelolaan dana desa di kecamatan Balong Kabupaten Madiun dengan studi kasus di desa Tatung dan desa Karangmojo meliputi pengelolaan dana desa di desa Tatung dan desa Karangmojo Kecamatan Balong serta dampak dari pemberdayaan di desa Tatung dan Karangmojo Kecamatan Balong.

\section{METODE PENELITIAN}

Metode penelitian kualitatif adalah metode penelitian yang berlandaskan pada filsafat postpositivisme, digunakan untuk meneliti pada kondisi obyek yang alamiah, dimana peneliti adalah sebagai instrument kunci, teknik pengumpulan data dilakukan secara trianggulasi. (Sugiono, 2010). Penelitian ini dilakukan di Kecamatan Balong Kabupaten Ponorogo dengan studi Kasus di Desa Tatung dan Desa Karangmojo. Menggunakan teknik pengumpulan data menurut sumber datanya menggunakan sumber primer dan sumber data sekunder. Sumber primer adalah sumber data yang langsung memberikan data kepada pengumpul data. Data primer diperoleh dengan melakukan wawancara dan observasi. Wawancara dilakukan dengan kepala desa Tatung dan Karangmojo karena dianggap paling mengetahui tentang objek atau situasi social yang akan diteliti, pemilik homestay, dan karang taruna. Melalui observasi, peneliti belajar tentang prilaku, dan makna dari prilaku tersebut. Marshall dalam Sugiono (2010). Observasi dilakukan di desa Tatung terhadap 1) Kondisi fisik tempat penelitian Desa Tatung meliputi Lingkungan obyek wisata, sarana dan prasara wisata 2) aktivitas masyarakat sehari-hari. Sedangkan Observasi di desa Karangmojo meliputi 1) Kondisi fisik tempat penelitian Desa Karangmojo meliputi sarana dan prasarana, kondisi pertanian, 2) aktivitas sehari-hari masyarakat. Data sekunder berupa studi kepustakaan yaitu pengumpulan data dari sejumlah literature berupa buku, jurnal, dokumentasi, memanfaatkan dokumen tertulis dan data dari internet. Metode analisis data meliputi pengumpulan data, reduksi data, penyajian data, dan pengambilan kesimpulan.

\section{HASIL DAN PEMBAHASAN}

Menurut Todaro (2011) orang-orang miskin adalah bahwa sebagian besar orang miskin hidup di daerah pedesaan yang menerangkan bahwa aktivitas mereka berada pada sector pertanian dan aktivitas lain yang terkait. Pengertian kemiskinan menurut worldbank adalah hidup dengan pendapatan dibawah 2 \$ per hari. Kecamatan Balong Kabupaten Ponorogo terletak di Provinsi Jawa Timur, Kecamatan Balong memiliki dua puluh desa. Dengan luas wilayah 5.696 hektar, setiap desa memiliki potensi yang berbeda - beda. Dengan jumlah penduduk pada tahun 2017 sebanyak 41565 jiwa.

Pemerintah Indonesia selama ini telah banyak menciptakan kebijakan untuk menanggulangi kemiskinan Berdasarkan data BPS pada tahun 2011 jumlah Rumah Tangga Sasaran (RTS) penduduk miskin di 
kecamatan Balong adalah 7832. Di desa Tatung 391 sedangkan di desa Karangmojo 209. 15.343 RTS di Kecamatan Balong sudah mendapatkan bantuan dari pemerintah melalui program Penanggulangan Kemiskinan antara lain Raskin (beras miskin) merupakan program bantuan pangan dari pemerintah Indonesia yang berupa penjualan beras di bawah harga pasar kepada penerima tertentu, Jamkesmas (Jaminan Kesehatan Masyarakat) merupakan program bantuan sosial untuk pelayanan kesehatan bagi fakir miskin dan tidak mampu yang iurannya dibayar oleh pemerintah, PKH (Program Keluarga Harapan) merupakan program pemberian bantuan social bersyarat kepada keluarga penerima manfaat PKH, dan BLSM (Bantuan Langsung Sementara Masyarakat) bantuan yang diberikan kepada masyarakat untuk menyambut kenaikan harga BBM yang terjadi pada 22 Juni 2013.

Kebijakan penanggulangan masalah kemiskinan di pedesaan sesuai dengan program Nawacita Presiden Jokowi tentang membangun desa dari pinggiran Desa biasanya memiliki karakteristik / potensi yang berbeda beda. sektor pertanian adalah sektor yang paling banyak menopang perekonomian di desa. Oleh sebab itu dibutuhkan suatu pengelolaan yang berbeda disetiap desa. Sehingga program pengelolaan dana desa oleh masyarakat di desa Tatung dan Karangmojo kecamatan Balong menyesuaikan dari keadaan dan potensi yang dimiliki desa tersebut.

\section{Pengelolaan dana desa di desa Tatung dan desa Karangmojo Kecamatan Balong}

$70 \%$ masyarakat desa Tatung dan Karangmojo bekerja di sector pertanian subsisten, sebagian lagi bekerja sebagai buruh migran dengan menjadi TKI (Tenaga Kerja Indonesia) / TKW ( Tenaga Kerja Wanita) ke Luar Negeri atau melakukan urbanisasi ke daerah lain dengan menjadi buruh pabrik. Hal ini disebabkan karena mayoritas masyarakat memiliki pendidikan dan ketermpilan yang rendah dan tidak ada pekerjaan lain yang bisa memperbaiki kehidupan mereka jika tetap berada di desa.

Dipilihnya bukit Gede yang terletak di desa Tatung sebagai tempat yang layak digunakan untuk olahraga Paralayang oleh Tim survai olahraga Paralayang Provinsi Jawa Timur. Melihat potensi ini kepala desa Tatung dan masyarakat desa mencoba menjadi tuan rumah Liga Paralayang ke 4 se Jatim, dari suksesnya acara tersebut berdampak pada peningkatan pendapatan masyarakat maka masyarakat desa Tatung bersedia mengelola potensi bukit Gede sebagai wahana wisata Paralayang sehingga kedepannya akan dikembangkan sebagai desa wisata. Wahana Paralayang merupakan wahana yang membutuhkan modal besar dan membutuhkan banyak persiapan dari masyarakat desa sendiri karena diharapkan tidak hanya manfaat ekonomi namun diharapkan dengan adanya wahana Paralayang di desa ini bisa mencetak atlet Paralayang dari desa ini.

Kemajuan pariwisata dan desa wisata yang mampu meningkatkan pendapatan masyarakat menjadikan banyak desa mengelola desanya sebagai desa wisata. Tetapi tidak semua desa bisa dijadikan sebagai desa wisata. Terdapat tiga factor sehingga desa siap dijadikan desa wisata antara lain Pertama, wilayah pedesaan memiliki potensi alam dan budaya yang relatif lebih otentik daripada wilayah perkotaan, masyarakat pedesaan masih menjalankan tradisi dan ritual-ritual budaya dan topografi yang cukup serasi. Kedua, wilayah pedesaan memiliki lingkungan fisik yang relatif masih asli atau belum banyak tercemar oleh ragam jenis polusi dibandingankan dengan kawasan perkotaan. Ketiga, dalam tingkat tertentu daerah pedesaan menghadapi perkembangan 
ekonomi yang relatif lambat, sehingga pemanfaatan potensi ekonomi, sosial dan budaya masyarakat lokal secara optimal merupakan alasan rasional dalam pengembangan pariwisata pedesaan (Damanik, 2013:69). Anak agung, 2017.

Salah satu prioritas pengeloaan dana desa digunakan untuk Pemberdayaan masyarakat desa. Pemberdayaan desa adalah upaya mengembangkan kemandirian dan kesejahteraan masyarakat dengan meningkatkan pengetahuan, sikap, keterampilan, prilaku kemampuan kesadaran, serta memanfaatkan sumber daya melalui penetapan kebijakan, program, kegiatan, dan pendampingan yang sesuai dengan esensi masalah dan prioritas kebutuhan masyarakat desa. Hal ini yang membuat pemerintah desa Tatung menyiapkan dua tahapan dalam mengembangkan desa wisata dengan dana desa.

Tahap pertama pemerintah desa mengalokasikan anggaran dana desa untuk memperbaiki sumber daya manusia dengan tujuan ketika desa wisata sudah dibuka maka semua masyarakat desa Tatunglah yang benar - benar mengelolanya sehingga dana desa tersebut tidak keluar dan dirasakan masyarakat dari daerah lain. Hal ini sesuai dengan apa yang diharapkan dari adanya kebijakan dana desa. Dana desa adalah dana yang bersumber dari APBN yang diperuntukkan bagi desa yang ditransfer melalui APBD kabupaten / kota dan diprioritaskan untuk pelaksanaan pembangunan dan pemberdayaan masyarakat desa (Kementrian keuangan, 2017).

Dalam tahap ini dibagi menjadi empat 1) Untuk mempersiapkan desa wisata khususunya Paralayang maka pemerintah desa mengirimkan empat anak yang masih SMP dan SMA untuk diklat Paralayang sampai mendapatakan sertifikat paralayang. Hal ini dipersiapkan agar mereka bisa menjadi tandem (Pemandu Paralayang). Setelah ada remaja tatung yang menjadi tandem maka Desa tatung siap menerima wisatawan yang ingin bermain paralayang setiap harinya. Selain ini diharapkan dari pelatihan ini akan melahirkan atlit Paralayang. 2) Pemerintah desa juga mengirimkan beberapa pemuda desa agar mendapatkan pelatihan sebagai pemandu wisata baik wisatawan local maupun wisatawan asing. Selain menjadi pemandu wisata untuk wahana paralayang juga pemandu wisata edukasi bertani yang akan dikembangkan. 3) peningkatan keterampilan perempuan dengan mengolah hasil panen buah bengkoang sebagai kripik atau olahan apapun yang dapat dijadikan buah tangan sehingga dapat meningkatkan nilai jual buah bengkoang karena banyaknya hasil panen buah bengkoang yang sampai ratusan ton, 4) peningkatan pengetahuan dan keterampilan kepada perempuan tentang cara menyajikan makanan dengan harga yang relative murah walaupun di tempat wisata. Hal ini penting karena akan membuat wisatawan terkesan dan ingin kembali lagi.

Tahap kedua dengan akan dibukanya desa wisata maka perlu menyiapkan sarana dan prasaranya. untuk membanguna sarana dan prasana pemerintah desa Tatung tidak hanya menggunakan anggaran dana desa, disisni Pemerintah kabupaten Ponorogo dan dinas pariwisata ikut mendukung pembangunan infrastruktur untuk mengembangkan desa wisata. Pemerintah desa mengalokasikan dana desa untuk membuat jalan menuju wahana Paralayang di puncak bukit gede dengan paving (gambar 1) dan dikerjakan oleh masyarakat setempat serta pembuatan tanda panah menuju tempat lokasi. Tersedianya homestay yang memanfaatkan rumah warga desa yang memiliki toilet yang memadai yang layak dijadikan homestay. Selain mengandalkan wahana Paralayang di lereng bukit gede rencananya akan dibangun wisata buatan yang akan di bentuk taman dan spot- spot foto selfi. 
Berbeda dengan Desa Tatung yang menggunakan dana desa untuk pengembangan desa wisata, dana desa di desa Karangmojo digunakan untuk Bumdes (Badan Usaha Milik Desa), Gapoktan (Gabungan Kelompok Tani), dan Infrastruktur. Pada awal Bumdes didirikan pemerintah desa Karangmojo dengan karang taruna dan masyarakat yang akan mengelolaanya melakukan studi banding tentang pengelolaan bumdes di desa Ponggok Klaten dan ke kecamatan Ngabar Kabupaten Ponorogo yang merupakan desa yang sudah berhasil dalam mengelola Bumdes. Hal ini bertujuan untuk meningkatkan SDM sehingga mampu mengelola bumdes. Usaha yang dipilih masyarakat sebagai Bumdes adalah membuat peternakan burung Lovebird yang dikelola oleh karang taruna dan sebagian warga, karena dinilai usaha ini bisa mendapatkan keuntungan besar dan banyak peminatnya. Namun sekarang karena harga burung lovebird tidak setinggi dulu sehingga dinilai kurang dapat memberikan dampak berupa peningkatan pendapatan masyarakat. Oleh sebab itu rencana kedepan Bumdes akan berganti membuat usaha peternakan kelinci dan burung puyuh. Hal ini disebabkan karena permintaan akan daging kelinci dan burung puyuh cukup banyak dan stabil.

Kedua dana desa di desa Karangmojo digunakan untuk memberikan bantuan kepada Gapoktan berupa traktor karena dulunya petani menyewa traktor untuk menggarap sawahnya. Ketiga dana desa digunakan untuk perbaikan dan pembuatan infrastruktur seperti selokan, sumur bor yang digunakan untuk pengairan sawah, plengsengan (Gambar.2), dan pelebaran sungai.

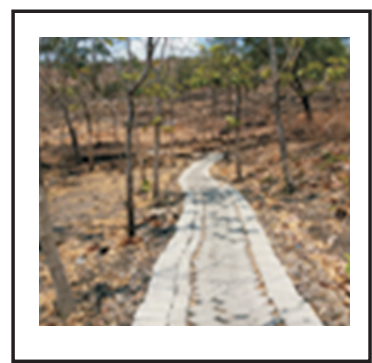

Gambar1.

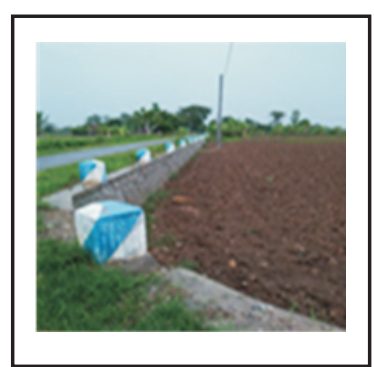

Gambar 2.

\section{Dampak dari pemberdayaan di desa Tatung dan Karangmojo kecamatan Balong}

Kesuksesan Turnamen Paralayang Jawa Timur ke empat yang telah diselenggarakan di desa Tatung selama tiga hari memberikan dampak berupa peningkatakan pendapatan bagi masyarakat desa mulai dari anak - anak sampai lanjut usia. Banyak anakanak yang bekerja membantu orang tuanya dengan menjadi tukang parkir. Banyaknya pengunjung/wisatawan ingin melihat Paralayang dan sulitnya akses menuju wahana Paralayang membuka peluang pemuda desa dengan menjadi tukang ojek, dalam sehari tukang ojek bisa puluhan kali mengantar pengunjung. Ibu - ibu banyak membuka warung makanan di pinggir jalan, rumah warga yang dipilih sebagai homestay juga menyediakan makanan sehingga menjadi peluang usaha bagi ibu- ibu disana. Dampak liga ini juga dirasakan oleh petani bengkoang yang sudah berusia lanjut membuka lapak di pinggir jalan.

Tahun depan ketika sumber daya manusia masyarakat yang meliputi Tandem Paralayang, pemandu wisata serta masyarakat desa Tatung sudah sadar wisata maka desa wisata dengan wahana Paralayang bisa dibuka sehingga dapat menerima wisatawan yang ingin bermain paralayang 
setiap hari. Dengan begitu dampaknya kesejahteraan masyarakat akan meningkat. Ketika kesejahteraan masyarakat meningkat maka kemungkinan akan mengurangi urbanisasi dan bekerja di luar negeri TKI/TKW. Di saat masyarakat sudah bisa mengelola sendiri maka penggunaan dana desa dengan pemberdayaan masyarakat dinilai berhasil sehingga Desa Tatung di tahun - tahun berikutnya sudah tidak lagi memerlukan dana desa karena desa tatung sudah mampu mandiri.

Sedangkan di desa Karangmojo, masyarakat desa sendiri yang bekerja membuat sumur bor, plengsengan, selokan, dan pelebaran sungai. Selain itu dari diperbaikinya infrastruktur ini maka berdampak pada peningkatan hasil pertanian. Penggunaan dana desa untuk infrastruktur juga terjadi di di Desa Wukisari Kecamatan Cangkringan Kabupaten Sleman, dalam penelitian ini penggunaan dana desa digunakan untuk pembangunan fisik dan implementasi kebijakan penggunaan dana desa dalam rangka peningkatan pembangunan di desa Wukirsari, Winarni (2016: 49). Serta pemberdayaan masyarakat berupa usaha ternak burung Lovebird. Hal ini telah sesuai dengan instruksi Presiden Indonesia tentang Cash for Work jadi dana desa tidak mengalir ke daerah lain dan dampaknya bisa mensejahterakan masyarakat desa itu sendiri.

\section{PENUTUP}

\section{Simpulan}

Di Desa Tatung dana desa dikelola sebagai desa wisata dengan fokus ke wahana wisata Paralayang. Pengelolaannya ada dua tahapan. Tahap pertama digunakan untuk peningkatan sumber daya manusia seperti mempersiapkan tandem, pemandu wisata, dan keterampilan pengolahan buah bengkoang. Sedangkan di desa Karangmojo digunakan untuk Bumdes sehingga sebagian warga dan karang taruna membuat usaha peternakan burung Love bird, bantuan pemberian traktor untuk Gapoktan, dan pembangunan infrastruktur seperti pembuatan sumur bor untuk pengairan sawah, plengsengan, dan pelebaran sungai.

Dampak yang dirasakan masyarakat desa Tatung setelah sukses menjadi tuan rumah tournament Paralayang bisa dirasakan mulai dari anak - anak sampai warga yang sudah lanjut usia. Dari sini terjadi perputaran uang yang sebelumnya masyarakat desa Tatung hanya mengandalkan pertanian. masyarakat desa sendiri yang bekerja membuat sumur bor, plengsengan, selokan, dan pelebaran sungai. Selain itu dari diperbaikinya infrastruktur ini maka berdampak pada peningkatan hasil pertanian. Serta pemberdayaan masyarakat berupa usaha ternak burung Lovebird. Hal ini telah sesuai dengan instruksi Presiden Indonesia tentang Cash for Work jadi dana desa tidak mengalir ke daerah lain dan dampaknya bisa mensejahterakan masyarakat desa itu sendiri.

\section{Saran}

Saran untuk desa Tatung sebaiknya mengajak kerjasama Universitas untuk menyiapkan Desa Wisata agar mendapat bantuan manajement desa wisata dan pengolahan produk bengkoang. Pengelolaan dana desa di Desa Karangmojo sebaiknya lebih digunakan kepada peningkatan pendapatan masyarakat dengan pemilihan usaha yang tepat.

\section{DAFTAR PUSTAKA}

Andriyani Aai etc. (2017). Pemberdayaan Masyarakat Melalui Pengembangan Desa Wisata Dan Implikasinya Terhadap Ketahanan Sosial Budaya Wilayah (Studi Di Desa Wisata Penglipuran Bali). Jurnal Ketahan Nasional. Volume 23 No.1, UGM, Yogyakarta, Indonesia 
Damanik, J. (2013). Pariwisata Indonesia Antara Peluang dan Tantangan, Pustaka Pelajar, Yogyakarta, Indonesia.

Pawito. (2007). Penelitian Komunikasi Kualitatif. Yogyakarta: LkiS.

Michael P. Todaro. Dan Stephen C. Smith. (2011). Economic Development/ Eleventh Edition. Terjemahan Agus Dharma. Penerbit Erlangga.

Peraturan Menteri Pariwisata Republik Indonesia Nomor 29 Tahun 2015 Tentang Rencana Strategis Kementerian Pariwisata Tahun 20152019
Sugiono. (2010). Metode Penelitian Kuantitatif Kualitatif dan $R \& D$. Bandung: Alfabeta.

Ummi dan Iqbal. (2017). Jurnal; ilmu pemerintahan http://.upstegal. ac.id/index. Php/jip

Winarni Fransisca dan Pandhu Yuanjaya. (2016). Implementasi Kebijakan dana Desa Dalam Meningkatkan Pembangunan di Desa Wukirsari Kabupaten Sleman. Natapraja Jurnal Kajian Ilmu Administrasi Negara Yogyakarta. Volume 4 Nomor 1. Universitas Negeri Yogyakarta. 